\title{
Redescription, systematic status and molecular characterisation of Multicaecum heterotis Petter, Vassiliadès et Marchand, 1979 (Nematoda: Heterocheilidae), an intestinal parasite of Heterotis niloticus (Osteichthyes: Arapaimidae) in Africa
}

\author{
Šárka Mašová ${ }^{1}$, František Moravec ${ }^{2}$, Vlastimil Baruš ${ }^{3}$ and Mária Seifertová ${ }^{1}$ \\ ${ }^{1}$ Department of Botany and Zoology, Faculty of Science, Masaryk University, Kotlářská 2, 61137 Brno, Czech Republic; \\ ${ }^{2}$ Institute of Parasitology, Biology Centre of the Academy of Sciences of the Czech Republic, Branišovská 31, 37005 České \\ Budějovice, Czech Republic; \\ ${ }^{3}$ Department of Zoology and Fisheries, Faculty of Agrobiology, Food and Natural Resources, Czech University of Life Sciences \\ Prague, Kamýcká 957, 16521 Prague 6 - Suchdol, Czech Republic
}

\begin{abstract}
Ascaridoid nematodes referable to Brevimulticaecum heterotis (Petter, Vassiliadès et Marchand, 1979) Khalil, 1984 were recorded from the intestine of the African bonytongue, Heterotis niloticus (Cuvier) (Arapaimidae, Osteoglossiformes), from the Mare Simenti in the Niokolo Koba National Park, East Senegal and from Kosti, Sudan. Their examination using light microscopy and for the first time both environmental scanning electron microscopy and scanning electron microscopy revealed some previously unreported morphological features and made possible a detailed redescription of this species. The most important finding is the presence of dentigerous ridges on the inner edges of the lips, which confirms the attribution of this species to Multicaecum Baylis, 1923, where it was originally placed, and not to Brevimulticaecum Mozgovoy in Skryabin, Shikhobalova et Mozgovoy, 1951 where it had subsequently been transferred. A key to Brevimulticaecum and Multicaecum species is provided. Multicaecum heterotis is the first species of the genus to be sequenced. Partial sequences of the small ribosomal subunit (18S) and internal transcribed spacer 2 region (ITS2) of nuclear ribosomal DNA (rDNA) have been analysed and compared with other nematode species.
\end{abstract}

Keywords: Nematoda, Brevimulticaecum, Multicaecum, Senegal, Sudan, Africa, Heterotis, barcoding, 18S rDNA sequences, ITS2 sequences

Heterotis niloticus (Cuvier) (Arapaimidae, Osteoglossiformes) is an opportunistic omnivorous freshwater fish. Olaosebikan and Raji (1998) stated that its standard length is $100 \mathrm{~cm}$ and its greatest published weight is $10.2 \mathrm{~kg}$ (Paugy et al. 2003). It is a foodfish and profitably cultured in Africa. Heterotis niloticus occurs in large rivers and lakes of the Nilo-Sudanian area in Central and West Africa and has been introduced into many rivers and aquaculture stations in Africa (Monentcham et al. 2009).

During a survey of fish parasites in the Niokolo Koba National Park (East Senegal) in the area of Mare Simenti and in Kosti, Sudan, ascaridoid nematode referable to Brevimulticaecum heterotis (Petter, Vassiliadès et Marchand, 1979) Khalil, 1984 were obtained from the intestine of the African bonytongue, Heterotis niloticus. Petter et al. (1979) described this species as Multicaecum heterotis from the same host in Senegal. However, because no denticular ridges on lips were reported in the original description, Khalil (1984) transferred this species to Brevi- multicaecum Mozgovoy in Skryabin, Shikhobalova et Mozgovoy, 1951.

The present study of these nematodes, using light microscopy (LM) and, for the first time, scanning electron microscopy (SEM) and environmental scanning electron microscopy (ESEM), revealed some previously unreported morphological features of taxonomic importance and made possible a detailed redescription of this species and the clarification of its generic allocation.

The partial sequences of the small ribosomal subunit (18S) and the internal transcribed spacer 2 (ITS2) region of nuclear ribosomal DNA (rDNA) were chosen as molecular markers for the taxonomic identification of this species. The 18S rDNA gene represents a well-conserved gene that evolves relatively slowly (Hillis and Dixon 1991) and seems to be an effective marker for the barcoding of nematode worms (Floyd et al. 2002). The ITS2 region is considered as an excellent tool for DNA diagnosis (Blouin 2002), because of its high variability, and

Address for correspondence: Š. Mašová, Department of Botany and Zoology, Faculty of Science, Masaryk University, Kotlářská 2 , 61137 Brno, Czech Republic. Phone: +420 549494 447; Fax: +420 541211 214; E-mail: masova@sci.muni.cz 
has become a popular choice for phylogenetic analysis of closely related species and populations.

\section{MATERIALS AND METHODS}

Four specimens of the African bonytongue, Heterotis niloticus (Cuvier), were examined. One of them was collected and dissected at Simenti $\left(13^{\circ} 01^{\prime} 33.4^{\prime \prime} \mathrm{N} ; 13^{\circ} 17^{\prime} 40.4^{\prime \prime} \mathrm{W}\right)$ in the Niokolo Koba National Park, East Senegal in 2004 and the other three at Kosti $\left(13^{\circ} 10^{\prime} 0^{\prime \prime} \mathrm{N} ; 32^{\circ} 40^{\prime} 0^{\prime \prime} \mathrm{E}\right)$ in the Sudan in 2006. A total of 92 nematode specimens were collected from the intestines at the first locality and 8 nematode specimens at the second. Recovered nematodes were washed in physiological saline $(0.9 \%)$ and immediately fixed in hot $4 \%$ formaldehyde solution. For molecular study, 4 specimens were fixed in $96 \%$ ethanol. For light microscopy, the nematodes were cleared with glycerine, after which they were examined using a light microscope equipped with differential interference contrast (DIC) optics, digital image analysis system (analySIS auto 5.0) and a drawing attachment. After examination, the specimens were stored in vials with $70 \%$ ethanol. Measurements are given in micrometres $(\mu \mathrm{m})$ unless otherwise stated, with the means in parentheses.

For SEM, 2 males and 3 females were used. Fixed specimens were dehydrated through a graded ethanol series, critical-point dried (in a Bal-Tec CPD 030 Critical Point Dryer) using liquid $\mathrm{CO}_{2}$, mounted on aluminium stubs with double-sided adhesive disc and sputter-coated with gold (in a Balzers SCD 040). The samples were examined using a Quanta ${ }^{\mathrm{TM}} 3 \mathrm{D}$ FEG scanning electron microscope at an accelerating voltage of $15 \mathrm{kV}$.

For ESEM, 1 male and 3 females were used. Fixed specimens were hydrated with water; desiccation was not carried out. A Quanta ${ }^{\mathrm{TM}} 250 \mathrm{FEG}$ at accelerating voltage of $15 \mathrm{kV}$ was used for specimen examination. ESEM observation was carried out at $100 \%$ relative humidity in the specimen chamber - where the sample was cooled down to $2^{\circ} \mathrm{C}$ in an atmosphere of water vapour at a pressure of 700-750 $\mathrm{Pa}$.

For the purposes of DNA barcoding, the partial sequences of the small ribosomal subunit (18S) and the internal transcribed spacer 2 (ITS2) region of nuclear ribosomal DNA (rDNA) were analysed. Genomic DNA was extracted from 4 ethanol-preserved specimens (2 from Senegal and 2 from the Sudan) using QIAamp DNA Mini Kit (Qiagen) and resuspended in $100 \mu \mathrm{l}$ AE buffer. PCR was carried out in $30 \mu \mathrm{l}$ of PCR reaction buffer with $2.5 \mathrm{mM} \mathrm{MgCl}_{2}, 200 \mu \mathrm{M}$ dNTPs, 0.5 unit of Taq DNA Polymerase (Fermentas) and $0.5 \mu \mathrm{M}$ of each primer (partial 18S or ITS2) using the Mastercycler ep gradient S (Eppendorf). The primers and the conditions used for PCR were as follows.

Partial 18S rDNA was amplified using forward primer Nem_18S_F and reverse primer Nem_18S_R designed by Floyd et al. (2005). The PCR mixture was denatured at $94^{\circ} \mathrm{C}$ for $5 \mathrm{~min}$, followed by 39 cycles at $94^{\circ} \mathrm{C}$ for $30 \mathrm{sec}, 52^{\circ} \mathrm{C}$ for $30 \mathrm{sec}$ and $72{ }^{\circ} \mathrm{C}$ for $1 \mathrm{~min}$, and the final extension at $72^{\circ} \mathrm{C}$ for $10 \mathrm{~min}$.

The ITS2 region was amplified using primers LC1-F and HC2-R (Navajas et al. 1992). The PCR mixture was denatured at $95^{\circ} \mathrm{C}$ for $2 \mathrm{~min}$, followed by 30 cycles at $95^{\circ} \mathrm{C}$ for $1 \mathrm{~min}$, $56^{\circ} \mathrm{C}$ for $45 \mathrm{sec}$ and $72^{\circ} \mathrm{C}$ for $3 \mathrm{~min}$, followed by final extension at $72^{\circ} \mathrm{C}$ for $10 \mathrm{~min}$.

PCR products were checked on GoldView-stained 1.5\% agarose gel and were purified by the High Pure PCR Product Purification Kit (Roche). Sequencing was carried out using BigDye ${ }^{\circledR}$ Terminator v3.1 Cycle Sequencing Kit and an Applied
Biosystems 3130 Genetic Analyzer. Sequencing for each sample was carried out for both strands. Nucleotide sequences of the partial 18S and ITS2 were edited using Sequencher software (Gene Codes Corporation, Ann Arbor, MI, USA) and aligned in BioEdit v. 7.0.9.0. (Hall 1999) using Clustal W multiple alignment (Thompson et al. 1994). BLAST searches were performed at http:/www.ncbi.nlm.nih.gov to look for related or similar species of nematodes.

Voucher specimens are deposited in the Helminthological Collection of the Institute of Parasitology, BC ASCR, in České Budějovice, Czech Republic (Cat. No. N-947) and other specimens in the Department of Botany and Zoology, Faculty of Science, Masaryk University, Brno, Czech Republic. Fish name follows FishBase (Froese and Pauly 2009).

\section{RESULTS}

Multicaecum heterotis Petter, Vassiliadès et Marchand, 1979

Figs. 1-24

Description: Medium-sized, whitish nematodes with 3 lips (Figs. 3 and 12-16); males not markedly smaller than females. Dorsal lip with two elliptical double papillae; each of two subventral lips with one elliptical single papilla and amphid, same wide as long, rounded margins and narrow postlabial grooves. Lower part of each lip with conspicuous cuticular striations; anterior part slightly striated. Labial pulp of each lip with two main branches ending anteriorly in short round cauliflower-like projections (Fig. 4). Small obtuse denticles arranged along inner margin of anterio-median border of lip; series of small denticles ends with one or two large denticles on both sides of lip (Fig. 16). Number of denticles 18 or 19; thickness of denticles $0.5-3.4$ (1.3). Interlabia pyramidal with undivided tip, approximately half length of lips. Wide lateral cuticular alae reach back to small distance posterior to oesophagus. Excretory pore at level or slightly posterior to nerve ring (Fig. 1); cervical papillae not observed. Oesophagus straight, terminating in ventriculus with two anterior and three short, knob-like posterior appendices (Figs. 2, 5). Intestinal caecum approximately half length of oesophagus.

Male (10 specimens from Senegal; measurements of 3 specimens from Sudan in brackets; means in parentheses): Length of body not markedly smaller than female, but more slender. Lips and interlabia 59-88 (72) [63-92 (75)] and 20-34 (27) [20-31 (27)] in length, respectively. Cervical alae 71-136 (109) [128-150 (139)], oesophagus 63-174 (107) [101-165 (132)] and intestinal caecum 78109 (96) [95-106 (100)] in maximum width. Ventriculus 115-204 (167) [157-191 (171)] long and 87-172 (123) [127-158 (146)] wide. Ventricular appendices 33-72 (50) [34-65 (55)] long. Two alate filiform spicules equal in form and length; distal tip non-alate and sharp (Figs. 8, 19, 20). Proximal and medial parts of spicule 23-27 (25) [21-25 (23)] and 11-17 (14) [10-13 (12)] wide, respectively. Gubernaculum slender in lateral view, triangular in 

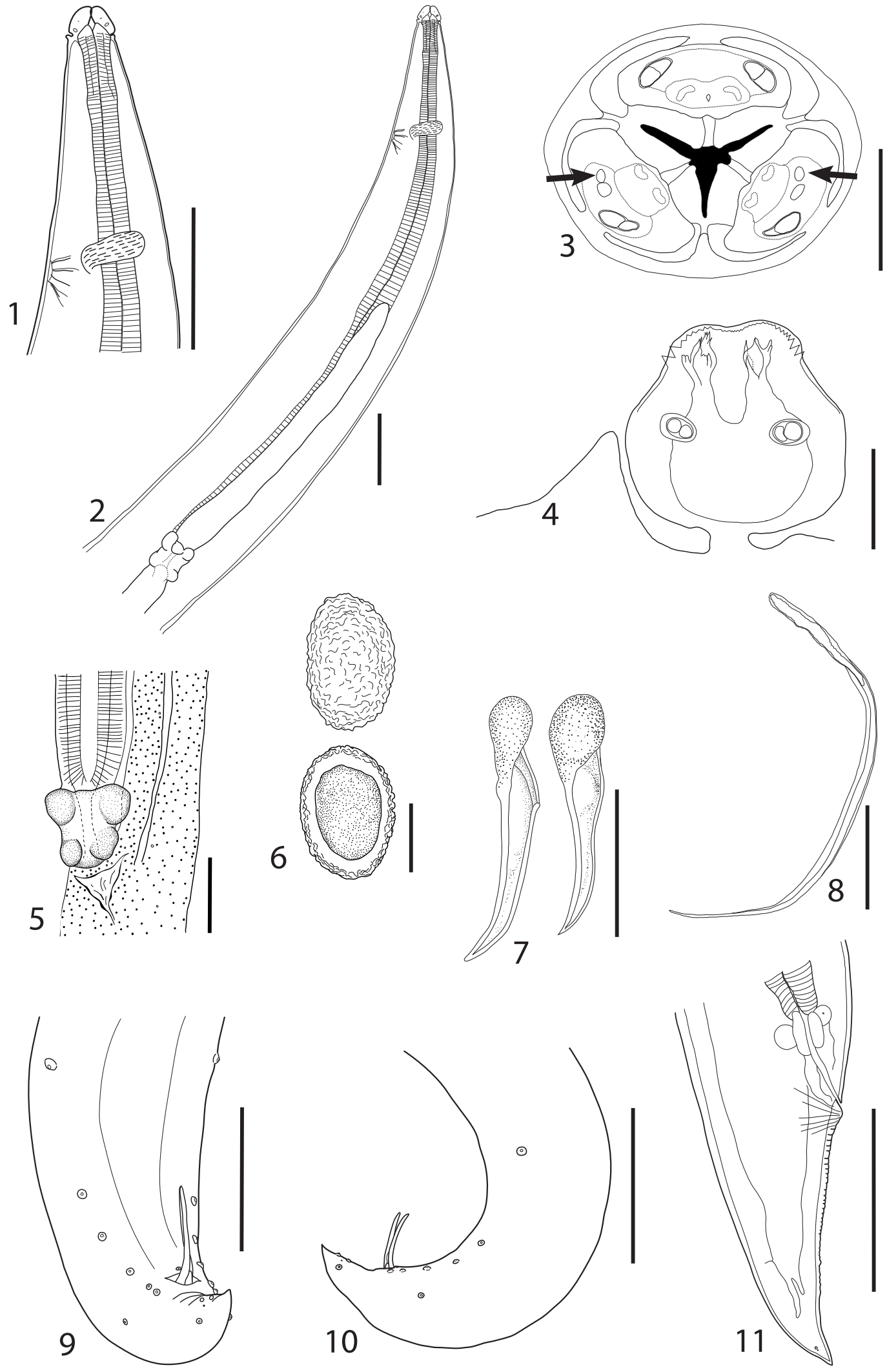

Figs. 1-11. Multicaecum heterotis Petter, Vassiliadès et Marchand, 1979; line drawings. Fig. 1. Lateral view of anterior end. Fig. 2. Oesophageal region with intestinal caecum and ventriculus. Fig. 3. Apical view of cephalic end; arrows indicate amphids. Fig. 4. Dorsal lip with interlabium. Fig. 5. Ventriculus. Fig. 6. Egg. Fig. 7. Gubernaculum. Fig. 8. Spicule. Fig. 9. Ventral view of male caudal end with papillae. Fig. 10. Lateral view of male caudal end with papillae. Fig. 11. Lateral view of female caudal end. Scale bars: Figs. 1, 2, 9=300 $\mu \mathrm{m}$; Figs. 3, 4, $6=50 \mu \mathrm{m}$; Figs. 5, $8=200 \mu \mathrm{m}$; Fig. $7=100 \mu \mathrm{m}$; Figs. 10, $11=400 \mu \mathrm{m}$. 

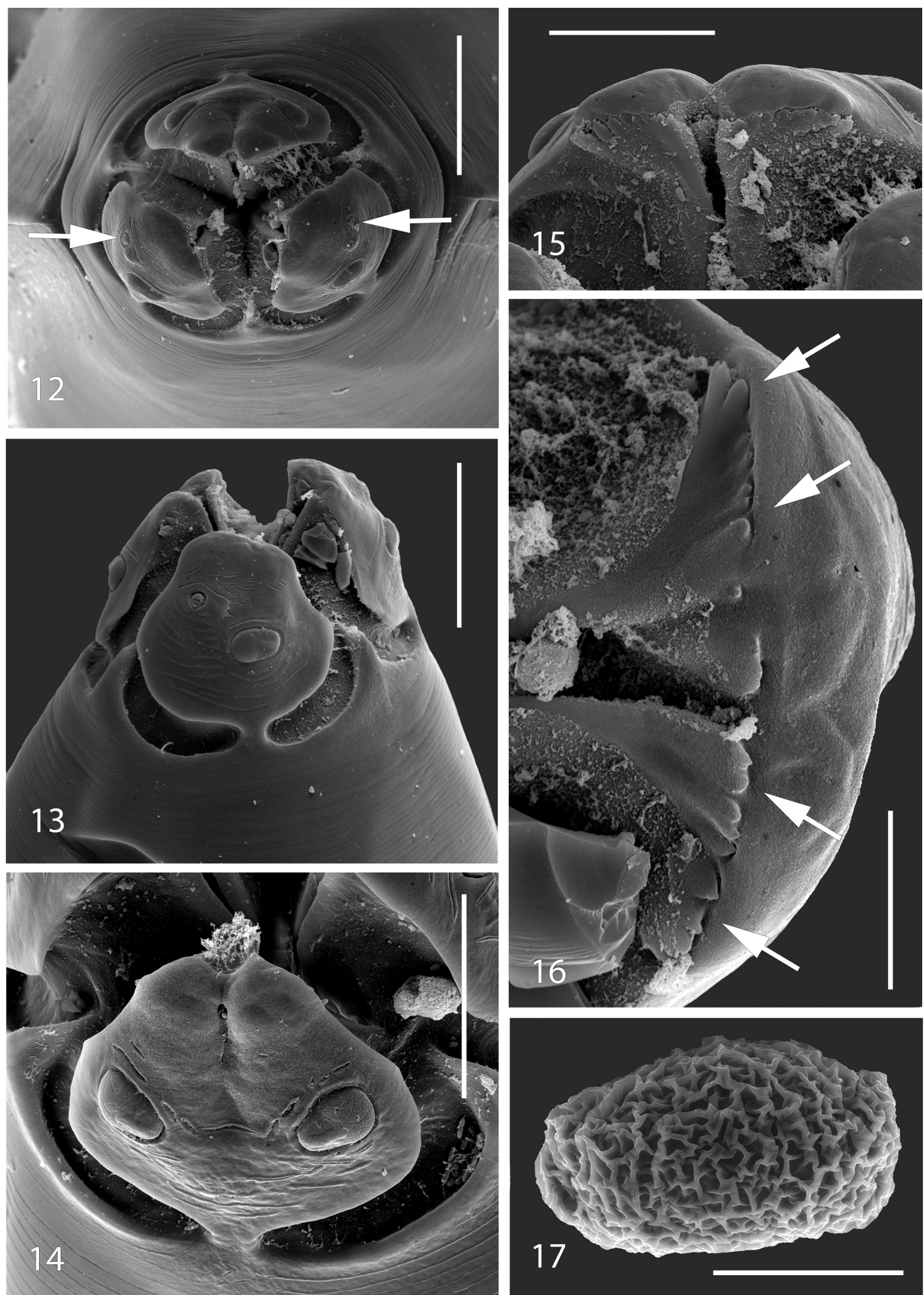

Figs. 12-17. Cephalic region of Multicaecum heterotis Petter, Vassiliadès et Marchand, 1979; scanning electron micrographs. Fig. 12. Apical view of cephalic end; arrows indicate amphids. Fig. 13. Lateral view of cephalic end. Fig. 14. Dorsal lip. Fig. 15. Inner view of lateroventral lip with teeth. Fig. 16. Detail of teeth of dorsal lip; arrows indicate teeth. Fig. 17. Egg. Scale bars: Figs. 12, $13=50 \mu \mathrm{m}$; Fig. $14=30 \mu \mathrm{m}$; Figs. 15, $17=20 \mu \mathrm{m}$; Fig. $16=10 \mu \mathrm{m}$. 
Table 1. Comparison of measurements of Multicaecum heterotis males (upper values) and females (lower values) from Senegal and Sudan with original description. Measurements are in micrometres unless otherwise stated.

\begin{tabular}{|c|c|c|c|c|c|}
\hline \multirow[t]{2}{*}{ Features } & \multirow[t]{2}{*}{$\begin{array}{l}0 \mathrm{n}=1 \\
0 \mathrm{n}=1\end{array}$} & \multicolumn{2}{|r|}{$\begin{array}{l}l n=10 \\
+n=5 \\
+\end{array}$} & \multicolumn{2}{|r|}{$\begin{array}{l}1 \\
\mathrm{n}=3 \\
0 \mathrm{n}=3\end{array}$} \\
\hline & & mean & range & mean & range \\
\hline Body length $[\mathrm{mm}]$ & $\begin{array}{c}20 \\
28.9\end{array}$ & $\begin{array}{l}20.92 \\
26.62\end{array}$ & $\begin{array}{l}15.27-31.00 \\
19.28-36.91\end{array}$ & $\begin{array}{l}18.99 \\
16.53\end{array}$ & $\begin{array}{l}16.32-21.32 \\
14.09-18.96\end{array}$ \\
\hline Body width & $\begin{array}{l}400 \\
500\end{array}$ & $\begin{array}{l}526 \\
612\end{array}$ & $\begin{array}{l}406-668 \\
460-851\end{array}$ & $\begin{array}{l}486 \\
393\end{array}$ & $\begin{array}{l}405-575 \\
372-419\end{array}$ \\
\hline Cervical alae from anterior & $\begin{array}{l}130 \\
200\end{array}$ & $\begin{array}{l}141 \\
166\end{array}$ & $\begin{array}{l}117-196 \\
120-194\end{array}$ & $\begin{array}{l}159 \\
145\end{array}$ & $\begin{array}{l}146-168 \\
120-169\end{array}$ \\
\hline Length of cervical alae [mm] & $\begin{array}{c}3.4 \\
4\end{array}$ & $\begin{array}{l}2.69 \\
2.99\end{array}$ & $\begin{array}{l}1.73-3.67 \\
2.01-4.02\end{array}$ & $\begin{array}{l}3.49 \\
3.90\end{array}$ & $\begin{array}{l}3.06-4.24 \\
3.00-5.26\end{array}$ \\
\hline Nerve ring from anterior & $\begin{array}{c}600 \\
1 \mathrm{~mm}\end{array}$ & $\begin{array}{l}573 \\
623\end{array}$ & $\begin{array}{l}456-735 \\
506-812\end{array}$ & $\begin{array}{l}634 \\
503\end{array}$ & $\begin{array}{l}545-791 \\
444-562\end{array}$ \\
\hline Excretory pore from anterior & $\begin{array}{c}800 \\
1.5 \mathrm{~mm}\end{array}$ & $\begin{array}{l}624 \\
711\end{array}$ & $\begin{array}{l}491-815 \\
551-995\end{array}$ & $\begin{array}{l}664 \\
566\end{array}$ & $\begin{array}{l}583-820 \\
505-627\end{array}$ \\
\hline Oesophagus length [mm] & $\begin{array}{c}3.8 \\
5\end{array}$ & $\begin{array}{l}3.04 \\
3.57\end{array}$ & $\begin{array}{l}2.22-4.02 \\
2.66-4.88\end{array}$ & $\begin{array}{l}3.32 \\
2.88\end{array}$ & $\begin{array}{l}2.77-3.65 \\
2.64-3.11\end{array}$ \\
\hline Intestinal caecum length [mm] & $\begin{array}{l}2.1 \\
2.8\end{array}$ & $\begin{array}{l}2.44 \\
3.29\end{array}$ & $\begin{array}{l}1.29-3.65 \\
2.19-4.33\end{array}$ & $\begin{array}{l}2.78 \\
2.48\end{array}$ & $\begin{array}{l}2.28-3.08 \\
2.15-2.71\end{array}$ \\
\hline Tail length & $\begin{array}{l}250 \\
600\end{array}$ & $\begin{array}{l}215 \\
621\end{array}$ & $\begin{array}{l}161-291 \\
461-802\end{array}$ & $\begin{array}{l}193 \\
391\end{array}$ & $\begin{array}{l}187-200 \\
316-467\end{array}$ \\
\hline Spicule length & $\begin{array}{c}1080 \\
-\end{array}$ & $\begin{array}{c}1038 \\
-\end{array}$ & $\begin{array}{c}920-1115 \\
-\end{array}$ & $\begin{array}{c}1025 \\
-\end{array}$ & $\begin{array}{c}919-1105 \\
-\end{array}$ \\
\hline Gubernaculum & $\begin{array}{c}230 \\
-\end{array}$ & $\begin{array}{c}212 \\
-\end{array}$ & $\begin{array}{c}181-238 \\
-\end{array}$ & $\begin{array}{c}230 \\
-\end{array}$ & $\begin{array}{c}220-243 \\
-\end{array}$ \\
\hline Vulva from anterior $[\mathrm{mm}]$ & 12.8 & $-\overline{-}$ & $8.36-14.98$ & $\overline{-} .93$ & $7.11-8.75$ \\
\hline Eggs & $90 \times \overline{-}$ & $96 \times 66$ & $88-101 \times 63-70$ & $90 \times 61$ & $82-102 \times 54-67$ \\
\hline Locality & $\begin{array}{l}\text { Richard Toll } \\
\text { (Senegal) }\end{array}$ & $\begin{array}{l}\text { Mare Sim } \\
\text { Nation }\end{array}$ & $\begin{array}{l}\text { enti, Niokolo Koba } \\
1 \text { Park (Senegal) }\end{array}$ & & sti (Sudan) \\
\hline Authors & Petter et al. 1979 & & Our & & \\
\hline
\end{tabular}

ventral view, with tapered rounded tip (Figs. 7, 20). Ten pairs of single caudal papillae and one papilla on upper cloacal lip (Figs. 9, 10, 18, 21-24). Five pairs of precloacal papillae (one pair lateral, four pairs subventral); two pairs of paracloacal papillae and three pairs of postcloacal papillae (one pair lateral, two pairs subventral). Sublateral phasmids present between both subventral postcloacal papillae. Tail tapered with conical tip (Fig. 24). Ratios: oesophagus $13-16 \%$ [17-18\%] of total body length; ventriculus 5-7\% [5-6\%] of oesophageal length; spicule $3-7 \%$ [4-6\%] of body length. For other measurements see Table 1.

Female (5 specimens from Senegal; measurements of 3 specimens from Sudan in brackets; means in parentheses): Body tapers gradually anteriorly; maximum width near middle of body. Lips and interlabium 74-99 (85) [65-66 (66)] and 21-44 (31) [24-25 (25)] long, respectively. Maximum width of cervical alae 103-132 (117) [75-83 (79)]. Oesophagus straight, with maximum width 128-180 (153) [85-133 (109)], continues as small ventriculus 142-252 (188) [138-149 (145)] in length and 116-209 (151) [114-142 (127)] in width; short obtuse ventricular appendices 41-86 (61) [43-58 (52)] long. Intestinal caecum 103-147 (122) [59-82 (71)] in maximum width. Vulva without salient lips or papilla, situated anterior to middle of body; vagina stout, relatively short, extends anteriorly and reflexes from undivided portion of uterus about same length as vagina; uterus divides into two branches. Vagina $1.15 \mathrm{~mm}$ long (length of vagina and undivided uterus $2.41 \mathrm{~mm}$ ) in Senegal female $21.72 \mathrm{~mm}$ long. In females 19.28-36.91 (26.62) mm [14.09-18.96 (16.53)] long, vulva situated at $41-45 \%$ [44-50\%] of body length from anterior end. Tail taperered with conical tip; phasmids situated laterally near caudal end; tail represents $2-3 \%$ [2\%] of total body length. Ratios: oesophagus $13-14 \%$ [16-19\%] of body length; ventriculus 5-6\% [5\%] of oesophageal length; intestinal caecum $82-97 \%$ [81-87\%] of oesophageal length. Eggs oval, with fine reticulate surface (Fig. 17). For other measurements see Table 1.

\section{DNA characterisation}

Partial 18S region. The sequences obtained of the partial $18 \mathrm{~S}$ rDNA were $854 \mathrm{bp}$ in length and show no intraspecific nucleotide variability. The similarity between the partial $18 \mathrm{~S}$ sequence of $M$. heterotis and other nematode sequences included in the alignment produced in BLAST varies from $92 \%$ to $98 \%$. Distance trees using fast minimum evolution and neighbour-joining methods constructed by BLAST clustered $M$. heterotis together with 

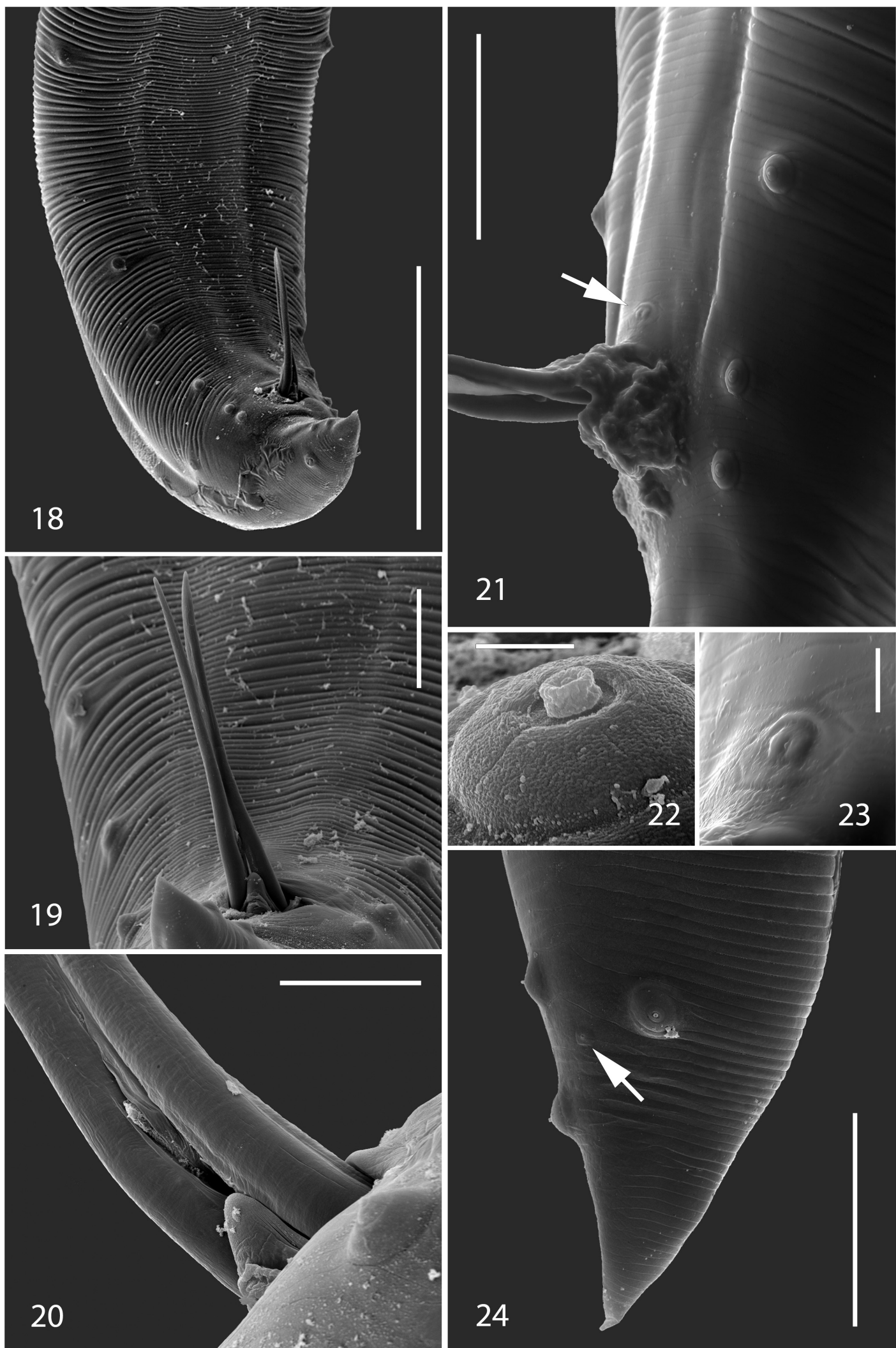

Figs. 18-24. Male of Multicaecum heterotis Petter, Vassiliadès et Marchand, 1979; scanning electron micrographs. Fig. 18. Caudal end with papillae. Fig. 19. Spicules. Fig. 20. Detail of spicules and distal tip of gubernaculum. Fig. 21. Arrow indicates location of precloacal papilla (ESEM). Fig. 22. Detail of caudal papilla. Fig. 23. Detail of precloacal papilla (ESEM). Fig. 24. Tail with postcloacal papillae and phasmid (arrow). Scale bars: Fig. $18=300 \mu \mathrm{m}$; Figs. 19, 20, $24=50 \mu \mathrm{m}$; Fig. $21=100 \mu \mathrm{m}$; Fig. $22=2 \mu \mathrm{m}$; Fig. $23=10 \mu \mathrm{m}$. 
Heterocheilus tunicatus Diesing, 1839 (accession number U94373.1) and showed that this species is related to other species of the Ascaridoidea available in GenBank. The partial $18 \mathrm{~S}$ sequence of $M$. heterotis was deposited in GenBank under accession numbers HM370518 and HM370519.

ITS2 region. A $418 \mathrm{bp}$ portion of the ITS2 region was amplified and sequenced. The resulting ITS2 sequence showed $88-100 \%$ homology, but only $8-27 \%$ coverage in relation to previously published nematode sequences using BLAST. Distance trees using fast minimum evolution and neighbour-joining methods produced by BLAST clustered $M$. heterotis together with a sub-cluster of 45 nematode sequences belonging to species of Anisakis Mozgovoy, 1951, Ascaris Linnaeus, 1758, Contracaecum Railiet et Henry, 1912, Hysterothylacium Ward et Magath, 1917, Porrocaecum Railiet et Henry, 1912, Raphidascaris Railiet et Henry, 1915 and Toxocara Stiles, 1905. The ITS2 sequence of M. heterotis was deposited in GenBank under accession numbers HM370520 and HM370521.

\section{DISCUSSION}

Baylis (1923) established the monotypic ascaridoid genus Multicaecum Baylis, 1923 to accommodate M. agile (Wedl, 1861) from Crocodylus niloticus Laurenti in the White Nile, Egypt. His generic diagnosis included the presence of dentigerous ridges on lips, small interlabia, and the oesophageal ventriculus with anterior and posterior oesophageal appendices. Later, several other species, mainly from crocodiles and gharials, were added to the genus (Skryabin et al. 1951, Mozgovoy 1953, Hartwich 1957). Travassos (1933a, b) pointed out that not all species of Multicaecum have dentigerous ridges on the lips. Based on this, Mozgovoy in Skryabin et al. (1951) divided this genus into two subgenera, the nominotypical subgenus Multicaecum (dentigerous ridges on lips present, ventricular appendices long and well developed, vulva anterior to middle of body) and Brevimulticaecum Mozgovoy in Skryabin et al., 1951 (dentigerous ridges absent, ventricular appendices reduced, vulva usually posterior to middle of body), with M. (B.) stekhoveni Baylis, 1937 as the type species. This was followed by Mozgovoy (1953). Later, Sprent (1979) redefined Brevimulticaecum and raised it to full generic status, incorrectly reporting B. baylisi (Travassos, 1933) as the type species.

Both Brevimulticaecum and Multicaecum contain species mainly parasitizing crocodiles, caimans and alligators. The first species parasitizing fishes was described from the African osteoglossiform Heterotis niloticus in Senegal as Multicaecum heterotis by Petter et al. (1979), which was subsequently transferred to Brevimulticaecum by Khalil (1984). Study of the present material from the type host and terra typica (Senegal) shows that the mor- phology of male and female specimens corresponds to the original description by Petter et al. (1979), with one major exception, which is the presence of dentigerous ridges on the internal edge of lips. The finding of this feature was enabled by the use of SEM and ESEM, and the subsequent detailed examination of the inner side of preparations of the lips under the light microscope. This difference from the original description can be explained by the fact that this taxon was not studied by SEM either by Petter et al. (1979), due to the small number of available specimens (2 males, 3 females), or by Sprent (1979), who had only one paratype female for study. Further findings of this species by Khalil (1984), Akinsanya (2007) and Akinsanya et al. (2007) were not studied using this method and the nematodes were not redescribed. The species M. agile was studied using SEM by Sprent (1979) and the presence of dentigerous ridges was demonstrated. Dentigerous ridges were not detected in B. baylisi (Travassos, 1933), B. stekhoveni (Baylis, 1947), B. tenuicolle (Rudolphi, 1819), Brevimulticaecum sp. - larvae, B. australiensis (Baylis, 1931), B. scleropagi Khalil, 1984, B. vandenbrandeni (Baylis, 1929) and B. regoi Sprent, 1990, which were also studied using SEM by Sprent (1978, 1979, 1990), Khalil (1984) and Reyda (2008). SEM was not used for the study of B. gibsoni (Sprent, 1979) and B. pintoi (Sprent, 1979).

Apparently, there are two groups of heterocheilid undoubtedly valid genera, one with dentigerous ridges ( 2 species) and the second one without them (9 species), corresponding to Multicaecum and Brevimulticaecum according to Sprent (1979). The weight of this feature is clearly of generic importance. In our opinion, the length of the ventricular appendices and the vulva placed anterior or posterior to the middle of body are not generic features. Gedoelstascaris Sprent, 1978 was regarded by Sprent (1990) as a synonym of Brevimulticaecum. The presence of dentigerous ridges in the species described by Petter et al. (1979) confirms that it actually belongs to Multicaecum, as originally designated by Baylis (1923).

Three species of Multicaecum and Brevimulticaecum are parasites of fishes and elasmobranchs: one of them has dentigerous ridges on the lips $(M$. heterotis, distribution in Africa: Senegal, Nigeria, Sudan described by Petter et al. 1979, Khalil 1984, Akinsanya 2007, Akinsanya et al. 2007) and two species lack this structure (B. scleropagi, hosts: Scleropages jardini (Saville-Kent) and S. leichardti Günther, Osteoglossidae, distribution Papua New Guinea and Australia - Khalil 1984, Sprent 1990; B. regoi, host: Potamotrygon motoro (Müller et Henle), Potamotrygonidae, distribution South America: Brazil - Sprent 1990, Reyda 2008).

Multicaecum heterotis significantly differs from $B$. scleropagi and B. regoi in the presence of dentigerous ridges, but also in possessing relatively broad cervi- 
cal alae (lateral alae absent in B. scleropagi and B. regoi) and in the spicule length (B. regoi $3.8 \mathrm{~mm}$; B. scleropagi 0.89-1.3 mm; $M$. heterotis 0.919-1.115 mm).

It should be noted that Maplestone (1930) described from Indian gharials Polycaecum gangeticum Maplestone, 1930. Travassos (1933a, b), Baylis (1936) and Hartwich (1957) considered this species a juvenile stage that should be included within Multicaecum. Among nematodes known from crocodilians in India and Ceylon, it is also necessary to mention Ascaris quadrata Linstow, 1904 from Crocodylus porosus (Schneider). In this nematode, the interlabia and dentigerous ridges on the lips were absent. Mozgovoy in Skryabin et al. (1951) transferred A. quadrata to Terranova Leiper et Atkinson, 1915. We respect Sprent's (1979) contention that both these taxons (P. gangeticum, A. quadrata) should be regarded as species inquirendae incertae sedis and not be included in Multicaecum.

With regard to geographical distribution, Multicaecum species have so far been found only in the Old World, extending from Africa, through India, to Australia. Brevimulticaecum species have so far been described from the New World, with the exception of one species parasitizing fishes in Papua New Guinea and Australia.

Multicaecum heterotis is the first species of the genus to have its small ribosomal subunit rDNA gene region and internal transcribed spacer 2 region sequenced for the purposes of species discrimination and identification. DNA analysis confirms the placement of $M$. heterotis within the Ascaridida and, moreover, it shows the position of $M$. heterotis in the molecular phylogenetic tree reconstructed in BLAST and supports the position of this nematode species based on morphological observations. Sprent (1979) considered the key features for the determination of species of Brevimulticaecum to be the spicule length (as a percentage of body length), the nature of the cuticular striation in the anterior region and, as a supplementary feature, the distance of the vulva from the anterior extremity (as a percentage of body length), the host and the distribution. Five species are considered in his key (B. baylisi, B. pintoi, B. tenuicolle, B. gibsoni and B. stekhoveni). In addition to the spicule length, we also use other morphological and metrical features in our key to determining the species of Multicaecum and Brevimulticaecum (lateral alae, gubernaculum length, female tail length, egg size). In our key, 11 valid species (2 Multicaecum and 9 Brevimulticaecum) are included.

\section{Key to Multicaecum and Brevimulticaecum species}

1 Dentigerous ridges on lips present ......... Multicaecum 2

- Dentigerous ridges on lips absent... Brevimulticaecum 3

2 Lateral cervical alae very narrow $(<40 \mu \mathrm{m})$; anterior prolongation of pulp short, obtuse and wide; posterior ventricular appendices longer than length of ventriculus; parasites of crocodiles in Africa, India and Australia ..... M. agile

- Lateral cervical alae wide $(71-150 \mu \mathrm{m})$; anterior prolongation of pulp almost reaches end of lip, pulp has two main branches ending anteriorly in short round projections; ventricular appendices shorter than length of ventriculus; parasites of fishes (Heterotis, Arapaimidae) in Africa M. heterotis

3 Narrow lateral cervical alae present ............................. 4

- Lateral cervical alae absent ........................................ 5

4 Vulva at $21-26 \%$ of body length from anterior end. In Melanosuchus niger; Brazil .......................... B. gibsoni

- Vulva at $43-52 \%$ of body length from anterior end. In Caiman latirostris and C. crocodylus; Brazil B. pintoi

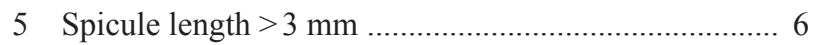

- Spicule length $<2 \mathrm{~mm}$............................................... 7

6 Spicule $3.8 \mathrm{~mm}$ long; eggs 55-71 $\times 49-55 \mu \mathrm{m}$. In freshwater stingray Potamotrygon motoro; Brazil B. regoi

- Spicule 5.1-6.5 mm long; eggs 58-82 × 42-71 $\mu \mathrm{m}$. In crocodilians (Caiman, Crocodylus); Brazil, Venezuela, Texas B. baylisi

$7 \quad$ Eggs $>100 \mu \mathrm{m}(102-114 \times 76-83)$; spicule 0.89 $1.30 \mathrm{~mm}$ long; parasites of fishes Scleropages jardini and S. leichardti; Papua New Guinea, Australia B. scleropagi

- Eggs $<95 \mu \mathrm{m}$; parasites of crocodiles in New World, Africa and Australia .. 8

8 Parasitic in African crocodiles (C. niloticus) (Angola, Republic of Congo, Zambia); spicules 1.2-1.3 mm long; gubernaculum $0.16 \mathrm{~mm}$ long; eggs $72-89 \times 58-79 \mu \mathrm{m}$.. . B. vandenbrandeni

- Parasitic in Australian and New World crocodiles ....... 9

9 Parasitic in Australian crocodiles C. johnstoni and C. porosus; spicules 1.0-1.7 mm long; gubernaculum 0.19-0.21 mm long; eggs 54-79 × 41-65 $\mu \mathrm{m}$ B. australiensis

- Parasitic in New World crocodiles 10

10 Parasitic in Alligator mississippiensis, USA; spicules 1.23-1.34 mm long; gubernaculum $0.17-0.18 \mathrm{~mm}$ long; eggs $53-81 \times 40-65 \mu \mathrm{m}$; spicules $7-11 \%$ of body length; vulva at $44-53 \%$ of body length from anterior end ........ B. tenuicolle

- Parasitic in Melanosuchus niger, Brazil; spicules 0.5-1.0 mm long; gubernaculum $0.15 \mathrm{~mm}$ long; eggs $71-93 \times$ 56-82 $\mu \mathrm{m}$; spicules $3.3-4.9 \%$ of body length; vulva at $36-53 \%$ of body length from anterior end.....

B. stekhoveni 
Acknowledgements. This study was supported by the Ichthyoparasitology Research Centre project No. LC522, by the long-term research plan MSM 0021622416 and by the research project of the Faculty of Agrobiology, Food and Natural Resources, Czech University of Life Sciences Prague, No. MSM 604607091 , both funded by the Ministry of Education, Youth and Sports of the Czech Republic, by the research project of the Institute of Parasitology, BC ASCR No. Z60220518, by the Czech Science Foundation grant No. 526/09/H025 and by the FEI Czech Republic. The authors are grateful to Božena Koubková, Department of Botany and Zoology, Masaryk University, Brno, Czech Republic and Tomáš Scholz, Department of Helminthology, Institute of Parasitology, BC ASCR for their great help in the field and for contributing the specimens.

\section{REFERENCES}

Akinsanya B. 2007: Histopathological study on the parasitised visceral organs of some fishes of Lekki Lagoon, Lagos, Nigeria. Life Sci. J. 4: 70-76.

Akinsanya B., Hassan A.A., Otubanjo O.A. 2007: A comparative study of the parasitic helminth fauna of Gymnarchus niloticus (Gymnarchidae) and Heterotis niloticus (Osteoglossidae) from Lekki Lagoon, Lagos, Nigeria. Pak. J. Biol. Sci. 10: 427-432.

BAylis H.A. 1923: On the classification of the Ascaridae. III. A revision of the genus Dujardinia Gedoelst, with a description of a new genus of Anisakidae from crocodile. Parasitology 15: 223-232.

BAYLIS H.A. 1936: The Fauna of British India, Including Ceylon and Burma. Nematoda (Ascaroidea and Strongyloidea). Vol. I. Taylor and Francis, London, 408 pp.

BLOUIN M.S. 2002: Molecular prospecting for cryptic species of nematodes: mitochondrial DNA versus internal transcribed spacer. Int. J. Parasitol. 32: 527-531.

Floyd R., Abebe E., Papert A., Blaxter M. 2002: Molecular barcodes for soil nematode identification. Mol. Ecol. 11: 839850.

Floyd R.M., Rogers A.D., Lambshead J.D., Smith C.R. 2005: Nematode-specific PCR primers for the $18 \mathrm{~S}$ small subunit rRNA gene. Mol. Ecol. Notes 5: 611-612.

Froese R., Pauly D. 2009: FishBase. World Wide Web electronic publication. www.fishbase.org, version 05/2009.

Hall T.A. 1999: BioEdit: a user-friendly biological sequence alignment editor and analysis program for Windows 95/98/NT, Nucleic Acids Symp. Ser. 41: 95-98.

Hartwich G. 1957: Zur Systematik der Nematoden-Superfamilie Ascaridoidea. Zool. Jahrb. Abt. Syst. Oekol. Geogr. Tiere 85: 211-252.

Hillis D.M., Dixon M.T. 1991: Ribosomal DNA molecular evolution and phylogenetic inference. Q. Rev. Biol. 66: 410-453.

KHALIL L.F. 1984: Brevimulticaecum scleropagi sp. nov. (Ascarididae: Nematoda) from the fish Scleropages jardini in $\mathrm{Pa}$ pua New Guinea. J. Nat. Hist. 18: 797-802.

Maplestone P. 1930: Parasitic nematodes obtained from animals dying in the Calcutta Zoological Gardens. Parts 1-3. Rec. Indian Mus. 32: 385-412.

Monentcham S.E., Kounm J., Pouomogne V., Kestemon P. 2009: Biology and prospect for aquaculture of African bony-

tongue, Heterotis niloticus (Cuvier, 1829): a review. Aquaculture 289: 191-198.

Mozgovoy A.A. 1953: [Ascaridata of Animals and Man and the Diseases Caused by Them. Essentials of Nematodology 2.] Akademiya Nauk SSSR, Moscow, 616 pp. (In Russian.)

Navajas M., Cotton D., Kreiter S., Gutierrez J. 1992: Molecular approach in spider mites (Acari: Tetranychidae): preliminary data on ribosomal DNA sequences. Exp. Appl. Acarol. 15: 211-218.

Olaosebikan B.D., Raji A. 1998: Field Guide to Nigerian Freshwater Fishes. Federal College of Freshwater Fisheries Technology, New Bussa, Nigeria, 106 pp.

Paugy D., Lévêque C., Teugels G.G. 2003: Poissons d'eaux douces et saumâtres de l'A frique de l'Ouest. Tome I. IRD Editions, Paris, $457 \mathrm{pp}$.

Petter A.J., Vassiliadès G., Marchand B. 1979: Une nouvelle espèce de Multicaecum (Ascarididae, Nematoda) parasite de poisson en Afrique. Bull. Inst. Fond. Afr. Noire 41: 324-329.

REYDA F.B. 2008: Intestinal helminths of freshwater stingrays in southeastern Peru, and a new genus and two new species of cestode. J. Parasitol. 94: 684-699.

Skryabin K.I., Shikhobalova N.P., Mozgovoy A.A. 1951: [Key to Parasitic Nematodes. Vol. II, Oxyurata and Ascaridata.] Akademiya Nauk SSSR Publishers, Moscow, 631 pp. (In Russian.)

Sprent J.F.A. 1978: Ascaridoid nematodes of amphibians and reptiles: Gedoelstascaris n. g. and Ortleppascaris n. g. J. Helminthol. 52: 261-282.

Sprent J.F.A. 1979: Ascaridoid nematodes of amphibians and reptiles: Multicaecum and Brevimulticaecum. J. Helminthol. 53: 91-116.

Sprent J.F.A. 1990: Some ascaridoid nematodes of fishes: Heterocheilinae. Syst. Parasitol. 16: 149-161.

Thompson J.D., Higgins D.G., Gibson T.J. 1994: CLUSTAL W: improving the sensitivity of progressive multiple sequence alignment through sequence weighting, position-specific gap penalties and weight matrix choice. Nucleic Acids Res. 22: 4673-4680.

Travassos L. 1933a: Sôbre os filarideos dos crocodilos SudAmericanos. Mem. Inst. Oswaldo Cruz 27: 159-164.

Travassos L. 1933b: Ascaridés des crocodiles Sud-Américains. C. R. Seances Soc. Biol. Fil. 114: 833-834. 